\title{
Optimization of Operational Application of Submarine-Launched Anti-Ship Missile to Sea Attack based on Time Effect Analysis
}

\author{
Hanguo Peng ${ }^{1 \mathrm{a}}$, Yangyang Zhao ${ }^{1 \mathrm{~b}}$ and Wei Yang ${ }^{1}$ \\ ${ }^{1}$ Naval Submarine Academic, Dalian, 116025, China \\ a446982051@qq.com, ${ }^{\text {b2 } 285892287 @ q q . c o m}$
}

Keywords: Submarine-launched anti-ship missile; An attack on the sea; Operational application

\begin{abstract}
This article from the analysis of various factors of affecting target designation timeliness, surface ships to submarine-launched anti-ship missile attack target designation problems urgently to be solved in a systematic theory and quantitative calculation are expounded. In the process of organizing and implementing the target instruction, some reasonable Suggestions with strong operability are put forward to solve the node problems that command organs and combat platforms need to pay attention to.
\end{abstract}

\section{Introduce}

In modern naval battles, the coordinated assault of multi-platform anti-ship missile will be the most sudden and damaging military operation. The coordinated assault requires the missile involved in the assault to fly to the target at the shortest interval. However, how to reach the air, sea, and even the shore-based underwater missile coordinated assault of different operations, such as platform within the prescribed time, is the command of troops and missile weapon organization, one of the biggest hurdles that security.

Submarines equipped with submarine-launched anti-ship maneuverable missile, the submarine concealment and missile assault force together, enable submarines and naval forces other collaborative remote assault on the enemy ships, can expand the assault target range (hit). However, in order to achieve accurate strike, the over-the-horizon guidance missile must have accurate, timely and effective target indication information.

\section{Enemy Target Information Necessary for the Combat Use of Submarine-launched Anti-ship Missiles}

Prior to the use of flying anti-ship missiles, the captain must obtain information about the enemy's maritime targets:

(1) Attribute of the target (mainly referring to nationality) to avoid complex situations such as diplomatic disputes caused by accidentally injuring the target of a third country;

(2) Coordinate and motion parameters of the target, i.e., deviation of longitude and latitude, target course $\mathrm{C}$, velocity $\mathrm{V}$, and related factors;

(3) Target type and formation. Target types are large, medium and small vessels. The formation of the target formation directly affects the commander and the attack and defense team's reasonable planning of the missile route and the decision of attack and defense.

In combat use, the quality of the above target information will affect the effectiveness and reliability of the target indication, and determine the effect of missile strike.

The precondition for organizing missile over-the-horizon assault is to obtain the target information and input it into the missile system in a stable, reliable, timely and accurate manner. The sources of information are as follows:

(1) Combat command

In combat command, the type of attack target, the number of ships in the group target, the composition, etc. For example, a group of several ships (transporters). The coxswain can make a precondition assessment of the target according to the combat command.

(2) Obtain target indication information through the internal information source of the submarine 
Submarine internal information sources refer to the detection and observation equipment on the submarine, which are divided into active information sources and passive information sources. The most direct way to obtain the target information is through the internal information source. For example, the target information that is automatically tracked by sonar is input into the automatic command and control system, and the time aging of the target information is minimal.

(3) Obtain target indicator information through external information sources

It mainly refers to the process when external information sources (naval reconnaissance force and equipment, reconnaissance satellite, etc.) obtain the target information and send it to the submarine through various channels. The submarine-launched anti-ship missile only attacks ships within the target's possible position domain. The more accurate the target elements are, the smaller the target's possible position domain will spread over time, and the better the missile penetration effect will be. The possible position domain size of the target is determined by the time aging of the target information under the condition of a certain detection error.

\section{The Four Stages of the Submarine's Missile Assault and the Corresponding Time Aging Amount}

The whole process of missile launch can be divided into four stages in time:

(1) Target indication stage

In this stage, the first time the aging of the target information appears. that is, the aging value of the target element to the submarine to obtain the target information. The reconnaissance force or equipment (collectively referred to as the target indicator source) confirms the coordinates, movement elements and errors of the target at $\mathrm{T}_{0}$ and sends the target information to the submarine after passing by. It is a key index to evaluate the timeliness of the target indication.

(2) Commander determination and operator manual input stage

In this stage, the captain after receiving target designation, according to the battlefield situation assessment for achieving goals, information plotting, set against determination, complete missile route planning, prediction launch time, ordered through fighting condition in the work, the work will lead to the amount of time aging target information.

Long accused the target information manually enter into automated command and control system to form a tactical situation table, the captain of a missile according to the command input attack methods according to the requirements of missile computation in the work station, route, weapon type, quantity, and combination of information. Hence, the time aging quantity $t_{\mathrm{jc}}$.

It is commonly referred to as the second time aging time before missile preparation. The time before missile readiness is a variable, depending on the readiness of submarines and missile systems, and the training of the captain and the combat team. In order to further improve the firing readiness and reaction time of the submarine, the parallel expansion method can be adopted in the specific implementation. For example, during the determination of the captain, the missile commander can simultaneously input to the system some solidified contents of the missile calculation, such as weapon type, quantity and type combination, etc.

(3) Pre-launch preparation stage of the missile

After completing the manual input, the captain calculates the pre-launch readiness according to the coordinated assault time, and orders "to switch on the combat conditions!" After the missile chief presses the "fight" button, the system completes the pre-launch preparation of the missile.

(4) Missile flight phase

The process from the missile's exit tube to the missile's arrival at the target is the final time aging of the target information. The submarine-launched anti-ship missile cruises at subsonic speeds (247 $+22 \mathrm{~m} / \mathrm{s}$ ) and has a 20-kilometer terminal penetration at supersonic speeds. The following formula can be used to calculate the flight time:

$$
t_{\text {fx }}=(D-20 k m) \cdot 1000 / 240+25
$$




\section{Valid Period of Target Information}

When organizing the target instruction, the target information not determined at any time can be used to organize the missile submarine to launch the missile at the specified time of attack. Premature target information does not guarantee that the missile will find the target at the specified probability. The belated target information will make it too late for the missile submarine to complete the assault at the specified time. The specific time of missile assault is specified, and the target instruction must be organized according to the time. For this reason, the command authority needs to determine an effective period of time according to the position of the fire array and transmit the target information determined during this period to the missile submarine, which is an effective target instruction.

Also known as shooting readiness time. At that time $\Delta t \succ 0$, indicating that there was time to complete the firing preparation; When $\Delta \mathrm{t}=0$, just can complete shooting preparation, this condition requires to complete shooting in the shortest time; When $\Delta t \prec 0$, obviously, there is not enough time to complete the preparation, it is necessary to reorganize the target instruction and improve the combat readiness of missile weapons and systems.

(1) Aging time analysis

The timeliness of target indication is generally evaluated by information aging time. Conceptually, aging time can be divided into target indicating aging time and total aging time.

Target designation refers to the aging time: since the last time from the source to determine the target information, the system complete preparation and mission, target information can be converted to the input to the missiles emitting tube moment between periods.

Total aging time refers to the time between the last time the target information is obtained from the information source and the time when the missile arrives at the target. It can be seen from the above formula that the total aging time increases the missile flight time based on the target indicating aging time. It depends on the missile strike program, the missile's flight distance. Associated with the target's spread (the missile's ballistic spread is proportional to the square of the plane), the basic principle of the system in calculating the flight mission is to minimize the missile's flight distance and time. This is because it is part of the total aging time. Therefore, in addition to consider when artificial missile assault scheme satisfies the requirement of battle and tactics, must also be consistent with the principle of calculating system as far as possible, try to avoid adding a useless missile route, artificially increase missile flight distance.

(2) Allowed full aging time

The allowable total aging time is that the aging value of the target information can ensure that the missile homing search band can cover the time range of the target's possible position area with a specified probability. The aging of target information is inevitable in the process of organizing missile assault. However, according to the specific assault scheme, the maximum allowable degree of information aging is mainly related to the performance of the missile and the search method of the self-guided head.

\section{The Simulation Verification}

Submarine anti-ship missile attacks sea targets in the possible position domain of the target. The possible position domain size of the target is determined by the total aging time and error diffusion speed of the target information. In missile firing, the weapon system will automatically calculate the probability of the missile homing search zone covering the target's possible position area. When the Russian navy conducts missile strikes, it requires that the probability value should not be less than 0.8. Otherwise, it believes that it may cause a waste of weapons. can be calculated based on various assault scheme allows the aging time (submarine-launched anti-ship missile homing head search, homing radar maximum Angle of a head for around $45^{\circ}$, the largest single target found distance of 40 kilometers, search with a maximum width of $30.5 \mathrm{~nm}$ ).

Use "the goal of the current position domain" method of missile attack, determining the mean 
square error of target location, then the limit error of aggressor forces the target to maximum speed according to the best of perpendicular to the direction of missile flight leave motor, can target maneuver width for the sea. The allowed total aging time is:

$$
t=S_{k} / V_{d \max }=16 / V_{d \max }
$$

Table 1 the allowed aging time for single target raid

\begin{tabular}{|c|c|c|c|c|c|c|c|c|}
\hline \multirow{2}{*}{$\begin{array}{c}\text { Positioni } \\
\text { ng mean } \\
\text { square } \\
\text { erroro }\end{array}$} & \multirow[t]{2}{*}{ Flight D } & \multirow{2}{*}{$\begin{array}{c}\text { Target } \\
\text { maximu } \\
\text { m speed }\end{array}$} & \multirow{2}{*}{$\begin{array}{l}\text { Permiss } \\
\text { ible } \\
\text { aging } \\
\text { time }\end{array}$} & \multirow[t]{2}{*}{$\mathrm{t}$} & \multirow[t]{2}{*}{$t_{i}$} & \multirow[t]{2}{*}{$t_{p}$} & \multirow[t]{2}{*}{$t_{f}$} & $\begin{array}{l}\text { information } \\
\text { duration }\end{array}$ \\
\hline & & & & & & & & $\Delta \mathrm{t}$ \\
\hline \multirow{6}{*}{$1 \mathrm{~km}$} & \multirow{3}{*}{$120 \mathrm{~km}$} & 15 & $64 \mathrm{~min}$ & \multirow{6}{*}{$3 \mathrm{~min}$} & \multirow{6}{*}{$2 \min$} & \multirow{6}{*}{$5 \mathrm{~min}$} & \multirow{3}{*}{$7.5 \mathrm{~min}$} & $46.5 \mathrm{~min}$ \\
\hline & & 24 & 40min & & & & & $22.5 \mathrm{~min}$ \\
\hline & & 40 & $24 \mathrm{~min}$ & & & & & $6.5 \mathrm{~min}$ \\
\hline & \multirow{3}{*}{$200 \mathrm{~km}$} & 15 & 64min & & & & \multirow{3}{*}{$13 \mathrm{~min}$} & $41 \mathrm{~min}$ \\
\hline & & 24 & 40min & & & & & $17 \mathrm{~min}$ \\
\hline & & 40 & $24 \mathrm{~min}$ & & & & & $1 \mathrm{~min}$ \\
\hline \multirow{6}{*}{$1.5 \mathrm{~km}$} & \multirow{3}{*}{$120 \mathrm{~km}$} & 15 & $58 \min$ & \multirow{6}{*}{$3 \mathrm{~min}$} & \multirow{6}{*}{$2 \mathrm{~min}$} & \multirow{6}{*}{$5 \mathrm{~min}$} & \multirow{3}{*}{$7.5 \mathrm{~min}$} & $40.5 \mathrm{~min}$ \\
\hline & & 24 & $36 \mathrm{~min}$ & & & & & $18.5 \mathrm{~min}$ \\
\hline & & 40 & $22 \mathrm{~min}$ & & & & & $4.5 \mathrm{~min}$ \\
\hline & \multirow{3}{*}{$200 \mathrm{~km}$} & 15 & $58 \min$ & & & & \multirow{3}{*}{$13 \mathrm{~min}$} & $35 \mathrm{~min}$ \\
\hline & & 24 & $36 \mathrm{~min}$ & & & & & $13 \min$ \\
\hline & & 40 & $22 \mathrm{~min}$ & & & & & $-1 \min$ \\
\hline
\end{tabular}

After the above quantitative analysis can be concluded that the missile assault, according to specific solution can approximate computing allows the aging time, compared with the aging time, it can evaluate the feasibility of shock solution, if, that solution can't achieve, or the effectiveness of missile assault is poor. It must be noted that in developing the missile attack plan, in order to ensure the effective implementation of the missile attack, the total aging time should be calculated according to this method. In the course of combat implementation, the corresponding adjustments can be made according to the specific battlefield situation target movement information.

Can be found by comparing different reconnaissance troops, ACTS as a source of target designation allowed when the aging time is not the same for submarines and reconnaissance aviation (for example), that is because, under the condition of modern submarine positioning precision of the low, low hidden determination of target location accuracy and long time needed for send assault submarine target information, the reliability is bad.

\section{References}

[1] Liwei L, Rongshuang F. Simulated annealing algorithm in solving frequency assignment problem[C]//Advanced Computer Theory and Engineering (ICACTE), 2010 3rd International Conference on. IEEE, 2010, 1: V1-361-V1-364.

[2] Castelino D J, Hurley S, Stephens N M. A tabu search algorithm for frequency assignment[J]. Annals of Operations Research, 1996, 63(2): 301-319.

[3] Alabau M, Idoumghar L, Schott R. New hybrid genetic algorithms for the frequency assignment problem[J]. Broadcasting, IEEE Transactions on, 2002, 48(1): 27-34.

[4] Radiom, S., Aliakbarian, H., etc., A Simple Real-Coded Compact Genetic Algorithm and its Application to Antenna Optimization, Microwave conference, APMC 2007.

[5] Francisco Herrera and Manuel Lozano. Gradual Distributed Real-Coded Genetic Algorithms [J]. IEEE transactions on evolutionary computation, 2000,4(1):43-62.

[6] Díógenes Marcano and Filinto Durán. Synthesis of [7]Antenna Arrays Using Genetic Algorithms [J]. IEEE Antennas and Propagation Magazine, 42(3):12-20. 
[8] Wen-Pin Liao, Fu-Lai Chu. Array pattern synthesis with null steering using genetic algorithm by controlling only the current amplitudes[J]. INT. J. ELECTRONICS, 1999, 86(4):445-457.

[9] Wen-Pin Liao, Fu-Lai Chu Application of Genetic Algorithms to Phase-Only Null Steering of Linear Arrays [J] Electromagnetics, 1997, 17:171-183.

[10]Fred Aust in, Michael lew is. Automated Maneuvering Decision for Air-to-Air Combat[R].AIAA-87-2393:659-669 